\title{
PERFORMANCE CHARACTERISTICS OF LACTATING DJALLONKÉ EWES FED RICE STRAW BASAL DIETS SUPPLEMENTED WITH STYLOSANTHES HAMATA
}

\author{
E.L.K. Osafo' ${ }^{1}$, V. Attoh-Kotoku', K. Oppong-Anane ${ }^{2}$, and K. Fynn ${ }^{3}$ \\ ${ }^{1}$ Department of Animal Science, College of Agriculture and Natural Resources, \\ Kwame Nkrumah University of Science and Technology, Kumasi. \\ ${ }^{2}$ Oporhu Agricultural and rural development consultancy limited, \\ P.O. Box CT1738, Accra, Ghana. \\ ${ }^{3}$ Sheep Breeding Farm, Ministry of Food and Agriculture, Ejura.
}

\begin{abstract}
A 7-week feed intake and growth performance study involving thirty lactating Djallonké ewes and their lambs was conducted. The ewes were randomly assigned to 3 dietary treatment groups resulting in 10 replications. The ewes were individually housed and offered $1000 \mathrm{~g}$ rice straw basal diet daily; Stylosanthes hamata given as a supplement at one of the 3 rates, which formed the treatments; i.e. $180 \mathrm{~g} / \mathrm{d}\left[\mathrm{T}_{180}\right], 240 \mathrm{~g} / \mathrm{d}\left[\mathrm{T}_{240}\right]$ or $360 \mathrm{~g} / \mathrm{d}\left[\mathrm{T}_{360}\right]$. Feed intake of the ewes and liveweight changes of the ewes and their lambs were recorded. Intake of rice straw was similar amongst the ewes on the different treatments $(P>0.05)$. However, the ewes consumed more supplement as the amount offered increased resulting in a significant improvement in total feed intake as the supplement offered increased $(P<0.01)$. There was no significant difference $(P>0.05)$ in the body weights of the ewes that could be attributable to treatment effects. The average daily gains (ADG) at day 49 for the lambs were, $47.5\left[T_{180}\right], 63.4\left[T_{240}\right]$ and $76 \mathrm{~g}\left[\mathrm{~T}_{360}\right]$. This result suggest that supplementation of ewes had a significant effect $(P<0.01)$ on the ADG of lambs as the level of supplementation increased. The results further indicate that supplementation of a basal rice straw diet with $360 \mathrm{~g}$ per day of Stylosanthes hamata enabled ewes to maintain their body weight in the dry season.
\end{abstract}

Keywords: supplementation, Stylosanthes hamata, rice straw, Djallonké ewes, lambs.

\section{INTRODUCTION}

The feed resources available to farmers in Ghana to feed the more than 3 million sheep (SRID, 2005) consist primarily of undeveloped communal pasture forages and crop residues (Siaw et al., 1993). Both feed resources are highly seasonal with quality and quantity decreasing as the dry season progresses. There is usually a correspond- ing lowering of the crude protein content, increase in dietary fibre and subsequent decrease in digestibility and intake, as the forage matures (Olson et al., 1994). Furthermore the major lambing occurs during the dry season (September-February) when feed resources are inadequate and of poor quality. This problem of inadequate feeding may lead to poor milk production by the ewe and subsequent 
starvation and death of lambs resulting in the high pre-weaning mortality noted among Ghanaian lambs (Buadu and Osafo, 1994). There is therefore the need to develop packages for dry season feeding to alleviate this problem.

Rice straw, as an alternative feed resource, could be used for stall-feeding of small ruminants, particularly lactating ewes in Ghana during the dry season. The current Government of Ghana policy of promoting local rice production and consumption implies that rice straw would be a feed resource that would be available to feed ruminants. Given the grain to straw ratio of 1: 1(Udo and ElHarith, 1985), it is estimated that 240,000 metric tonnes of rice straw would be available annually from the 240,000 metric tonnes of rice grains produced. Rice straw, however, contains only $4 \%$ crude protein (CP) (Ngwa and Tawah, 1991) and feeding rice straw alone would thus not be enough to meet maintenance and production requirements of lactating sheep and their lambs. There is therefore the need to identify a protein source that should be cheap and be able to increase the intake and digestibility in sheep fed rice straw and meet the nutrient requirements of lactating ewes.

Amongst the most promising forage supplements that could improve utilisation of roughage on small holder ruminant farms by providing nitrogen in the rumen are the Stylosanthes species. The most important is the accession Stylosanthes hamata, which has proved to be resistant to the fungal disease called Anthracnose that affects most accessions notably, Stylosanthes guianensis (Humphreys, 1991).

In order to sustain the productivity of small ruminant livestock in Ghana, there is the need to develop a feeding system based on a low cost basal diet. Rice straw supplementation with $S$. hamata seems to be a promising combination to address this.

The objectives of this work were to determine the effects of the supplementation of a rice straw basal diet with Stylosanthes hamata on the feed intake and liveweight changes of lactating ewes, feed conversion ratio as well as the implications of these effects on the suckling lambs.

\section{MATERIALS AND METHODS Location of study}

The study was carried out at the Sheep Breeding Farm of the Ministry of Food and Agriculture (MOFA), at Bonyon, Ejura, in the Ejura-SekyereDumasi District of the Ashanti Region. Ejura is situated at latitude $7^{\circ}, 23^{\prime} \mathrm{N}$ and longitude $1^{\circ}$, $21^{\prime} \mathrm{W}$. The study was carried out from December 2001 to March 2002.

\section{Source of Feeds}

The rice straw of the November (2001) to February (2002) harvesting season was obtained from smallholder rice farms in and around Ejura after the harvest of the grains. The straw was baled using a mechanical baler and transported to the Sheep Breeding Farm and stored under a shed.

\section{Experimental Design}

Thirty (30) lactating Djallonké ewes in their fourth week of lactation were used in a completely randomised design (CRD) feeding trial over a 7week period. The ewes were ranked according to body weight and randomly allocated to three dietary treatments namely $\mathrm{T}_{180}, \mathrm{~T}_{240}$ and $\mathrm{T}_{360}$ with ten replicates per treatment. Rice straw constituted the basal diet and was offered at $50 \mathrm{~g} / \mathrm{kg}$ liveweight (LWT)/day while the Stylosanthes hamata provided as a supplement at the rate of $180\left(\mathrm{~T}_{180}\right)$; $240\left(\mathrm{~T}_{240}\right)$ or $360\left(\mathrm{~T}_{360}\right) \mathrm{g} /$ day. The $S$. hamata used was harvested from the fields of the Sheep Breeding Farm, Ejura.

The three dietary treatments therefore were as follows:

$$
\begin{aligned}
& \mathrm{T}_{180}= 50 \mathrm{~g} / \mathrm{kg} \text { LWT } / \text { day rice straw }+180 \mathrm{~g} / \text { day } \\
& \text { Stylosanthes hamata. } \\
& \mathrm{T}_{240}=\quad \begin{array}{l}
50 \mathrm{~g} / \mathrm{kg} \text { LWT } / \text { day rice straw }+240 \mathrm{~g} / \text { day } \\
\text { Stylosanthes hamata. }
\end{array} \\
& \mathrm{T}_{360}=\quad \begin{array}{l}
50 \mathrm{~g} / \mathrm{kg} \mathrm{LWT} / \text { day rice straw }+360 \mathrm{~g} / \text { day } \\
\text { Stylosanthes hamata. }
\end{array}
\end{aligned}
$$




\section{Animals and Management}

The ewes and their lambs were identified by plastic ear tags and housed in individual wellventilated pens measuring $(3 \times 1 \mathrm{~m})$. The pens were cleaned and disinfected for a week before the commencement of the study. Albendazole $10 \%$, a broad-spectrum antihelminthic, was administered as a drench for the control of internal parasites. 'Deadline' "Pour-on,"2 an acaricide, was used for the control of external parasites following the manufacturer's instructions.

\section{Diet Preparation and Feeding}

The Stylosanthes was harvested and sun dried on concrete floors for 2 - 3 days before being fed to the experimental animals. The basal diet, rice straw, was chopped into about $8-10 \mathrm{~cm}$ in length, weighed and offered to the sheep. The lactating ewes were individually offered $1000 \mathrm{~g}$ rice straw and Stylosanthes hamata was given at one of the three levels (i.e. $180 \mathrm{~g} / \mathrm{d}$ or $240 \mathrm{~g} / \mathrm{d}$ or $360 \mathrm{~g} / \mathrm{d}$ ) according to the treatment assigned. The diets were offered in wooden feeding troughs and water was supplied in 10 litre plastic bowls. Mineral salt lick $^{3}$ was supplied ad libitum. The straw ration for the day was offered as two equal meals at 9.00 a.m. and 4.00 p.m. The supplement was also divided into two and offered twice daily, an hour before the provision of the rice straw. The basal diet was only offered on complete consumption of the supplement.

\section{Data collection}

Feed offered and refusals were recorded daily, for the 49-day duration of the experiment at 8.00 a.m from which daily feed intake was subsequently calculated. Samples of the rice straw and Stylosanthes and refusals per pen were bulked per pen over a 7-day period and sub-samples taken for chemical analysis. No attempt was made at estimating milk consumed by the lambs or water consumption by the ewes because of the lack of labour. Feed conversion ratios were calculated as feed intake divided by weight gain.

\section{Growth Measurements}

The ewes were weighed at the beginning and the end of the experiment to establish the initial and final live weights respectively. Feed and water were withdrawn twelve hours before weighing. The lambs on the other hand were weighed every ten days.

\section{Chemical Analyses}

The samples were thoroughly mixed and subsamples taken for milling prior to chemical analysis. Samples of the feed ingredients and feed refusals were ground using a hammer mill (Cyclotec 1093 Sample Mill) with a $1 \mathrm{~mm}$ screen. The samples were then analysed for dry matter (DM), crude protein $(\mathrm{CP})$ and ash contents based on the procedures of the AOAC (1990). Acid detergent fibre (ADF) and neutral detergent fibre (NDF) were analysed using the methods of Goering and van Soest (1970). Hemicellulose levels in the feed stuffs were determined as the difference between NDF and ADF values.

\section{RESULTS}

The ewes remained in good health throughout the trial. There was however an outbreak of ovine pneumonia one and a half months into the trial and 5 lambs and a ewe succumbed to the disease even though treatment was initiated. The deaths were spread across all the treatment groups two died in treatments $T_{180}$ and $T_{240}$ and one lamb in $\mathrm{T}_{360}$.

\section{Quality of rice straw and Stylosanthes used}

The chemical composition of the feed offered the sheep is presented in Table 1. The results show that both the rice straw and Stylosanthes had DM

${ }^{1}$ Albendazole $10 \%$-: Pyvet Holland. Contains $100 \mathrm{mg}$ albendazole/ $\mathrm{ml}$

${ }^{2}$ Deadline "Pour-on": Bayer (Pty) Ltd., Animal Health Divition, Namibia. Contains-: Flumethrine $1 \%$ w $/ v$.

${ }^{3}$ Mineral salt lick, La Veterinary Hospital. Contains-: $2500 \mathrm{~g}$ magnesium; $1800 \mathrm{~g}$ iron; $380 \mathrm{~g}$ manganese; $280 \mathrm{~g}$ zinc; $110 \mathrm{~g}$ cobalt; $110 \mathrm{~g}$ iodine; and $3 \mathrm{~g}$ selenium $/ \mathrm{kg}$ 
levels of more than $960 \mathrm{~g} / \mathrm{kg}$. The crude protein content of the legume was higher, being nearly three times that of the rice straw but the fibre and ash contents of the rice straw were higher than the values for the Stylosanthes. Furthermore, the rice straw contained silica, which was not found in the legume

\section{Liveweight change and feed intake of lactating ewes}

Table 2 shows the liveweights and feed intake of the ewes. The results show that there were no differences in the liveweights due to treatment effects $(\mathrm{P}>0.05)$. However, there were marginal increases in the final liveweight of the ewes over the period of the experiment, these being 1.3, 1.5 and $1.8 \mathrm{~kg}$ for treatments $\mathrm{T}_{180}, \mathrm{~T}_{240}$, and $\mathrm{T}_{360}$, respectively.

The daily rice straw intake by the ewes was similar for all treatments $(\mathrm{P}>0.05)$. However, intake of Stylosanthes, significantly increased $(\mathrm{P}<0.01)$ as the offer rate increased resulting in a significantly $(\mathrm{P}<0.01)$ higher total feed intake. Ewes offered $360 \mathrm{~g}$ Stylosanthes had the highest total feed intake. When total feed intake was expressed on metabolic weight basis, there were no differences due to treatment effects $(\mathrm{P}>0.05)$.

Table 1: Chemical composition of rice straw (Oryza sativa) and Stylosanthes hamata

\begin{tabular}{lcccc}
\hline Item & Rice Straw & SD & Stylosanthes & SD \\
\hline Dry Matter (DM) (g/kg) & 969.6 & 1.54 & 962.4 & 0.66 \\
Crude Protein (g/kg DM) & 36.4 & 0.17 & 114.8 & 0.26 \\
$\mathrm{NDF}^{\#}$ (g/kg DM) & 801.6 & 0.95 & 512.6 & 0.36 \\
$\mathrm{ADF}^{\#}$ (g/kg DM) & 505.1 & 0.53 & 395.9 & 0.79 \\
Hemicellulose (g/kg DM) $_{\text {Ash (g/kg DM) }}^{296.5}$ & 0.66 & 116.7 & 0.36 \\
Silica (g/kg DM) & 122.2 & 0.44 & 71.1 & 0.35 \\
\hline
\end{tabular}

$N D F^{\#}$, neutral detergent fibre; $A D F$, acid detergent fibre; $S D$, standard deviation

Table 2: Live weight change and intake of straw and Stylosanthes by the ewes

\begin{tabular}{|c|c|c|c|c|c|}
\hline & \multicolumn{5}{|c|}{ Treatments } \\
\hline & $\mathbf{T}_{180}$ & $\mathbf{T}_{240}$ & $\mathbf{T}_{360}$ & SE & Sig \\
\hline Initial weight $[\mathrm{M}], \mathrm{kg}$. & 19.4 & 19.7 & 21.7 & 0.89 & NS \\
\hline Final weight $[\mathrm{M}], \mathrm{kg}$. & 20.7 & 21.2 & 23.5 & 1.03 & NS \\
\hline Initial metabolic weight $\mathrm{M}^{0.75}$ & 9.2 & 9.3 & 10.0 & 0.28 & NS \\
\hline Final metabolic weight $\mathrm{M}^{0.75}$ & 9.7 & 9.9 & 10.6 & 0.36 & NS \\
\hline \multicolumn{6}{|l|}{ Intake } \\
\hline Straw (g DM/d) & 808.8 & 832.8 & 820.3 & 23.76 & NS \\
\hline Stylosanthes (g DM/d) & 166.3 & 222.9 & 323.7 & 4.12 & $* * *$ \\
\hline Total (g DM/d) & 975.1 & $1,055.7$ & $1,144.0$ & 24.46 & $* *$ \\
\hline Straw intake $\left(\mathrm{g} \mathrm{DM} / \mathrm{M}^{0.75} / \mathrm{d}\right)$ & 88.0 & 88.9 & 83.2 & 3.60 & NS \\
\hline Stylo intake (g DM/M $\left.{ }^{0.75} / \mathrm{d}\right)$ & 18.1 & 24.1 & 32.9 & 1.09 & $* * *$ \\
\hline Total $\left(\mathrm{g} \mathrm{DM} / \mathrm{M}^{0.75} / \mathrm{d}\right)$ & 106.1 & 113.0 & 116.1 & 4.44 & NS \\
\hline
\end{tabular}

NS, Non-significance; *, $P<0.05 ; * *, P<0.01 ; * * *, P<0.001 ;$ SE, Standard error. 


\section{Live weight changes of lambs}

Table 3 shows the lamb live weight changes over the period of the experiment. There were no significant differences in initial liveweights of the lambs ( $>0.05)$. However, significant changes $(\mathrm{P}<0.01)$ had occurred in their liveweights by day 49 of the experiment with $\mathrm{T}_{360}$ lambs being the heaviest and having significantly higher $(\mathrm{P}<0.01)$ ADG than the other treatment groups. The ADG during the period (49 days) were $47.5,63.4$, and $76.0 \mathrm{~g}$ per day for the lambs of the lactating ewes fed 180, 240 and $360 \mathrm{~g}$ Stylosanthes, respectively.

\section{DISCUSSION}

Feed intake and live weight changes in ewes

The high dry matter of both the rice straw and Stylosanthes indicate that the feed offered were quite dry. The low crude protein content of the rice straw used in this experiment is a typical value for rice straws (Tuen et al., 1991; Vadiveloo, 1992) and therefore when such feed is offered, there is always the need to supplement so as to enable the animals meet their protein requirements for high levels of production (Leng, 1990). The Stylosanthes hay offered had a higher $\mathrm{CP}$ content. The value is similar to those observed by Rai et al. (1998), Rodriquez et al. (1998) and Cesar et al. (1999). The Stylosanthes was therefore a suitable protein supplement for the low protein rice straw basal diet.
The non-significant difference $(\mathrm{P}>0.05)$ observed in rice straw intake amongst the three treatments coupled with the increased intake of $S$. hamata as the supplements offer rate increased implies that there was no substitution effect. Therefore higher levels of the supplement could be fed. Values for the total dry matter intake (DMI) with Stylosanthes supplementation of straws obtained from this experiment were generally comparable to those reported by others for sheep (Ngwa and Tawah, 1991; Njwe and Kona, 1998; Arigbede et al., 2004). Rodriquez et al. (1998) reported improved DMI as the level of inclusion of the supplement, Stylosanthes, increased. Similar observations were noted when weaned lambs were fattened on Chloris gayana hay with lablab (Dolichos lablab) meal as protein supplement where increasing the crude protein content of diet resulted in higher dry matter intakes (Mafwere and Mtenga, 1992).

This study suggests that, supplementation of a rice straw basal diet with $360 \mathrm{~g} /$ day of S.hamata resulted in increased total DMI thereby corroborating the observations of Arigbede et al. (2004) and Ngi et al. (2006). The increased intake is probably due to a reduction in the mean retention time and also an increase in the animals' state of N-balance (McManus et al., 1972; Moran et al., 1983). Van Soest (1982) also indicated that supplementation with protein, tends to have a positive effect of increasing microbial population with an increase

Table 3: The effect of Stylosanthes supplementation of Djallonkè ewes on the preweaning live weight change of the lambs.

\begin{tabular}{lccccc}
\hline & \multicolumn{3}{c}{ Treatment } & \multicolumn{2}{c}{ Sig. } \\
\hline Initial weight [M], kg & $\mathbf{T}_{\underline{\mathbf{1 8 0}}}$ & $\mathbf{T}_{\mathbf{2 4 0}}$ & $\mathbf{T}_{\mathbf{3 6 0}}$ & $\mathbf{S E}$ & NS \\
& 4.1 & 4.1 & 4.7 & 0.29 & \\
Initial metabolic weight $\mathrm{M}^{0.75}$ & 2.9 & 2.9 & 3.2 & 0.15 & NS \\
49 day weight [M], kg & 6.2 & 7.5 & 8.9 & 0.38 & $*$ \\
49-day metabolic weight $\mathrm{M}^{0.75}$ & 4.0 & 4.4 & 5.0 & 0.21 & $* *$ \\
49 day ADG, g/day & 47.5 & 63.4 & 76.0 & 5.69 & $* *$ \\
\hline
\end{tabular}

$A D G$, average daily gain; SE, standard error; NS; *, $P<0.05 ; * *, P<0.01 ; * * *, P<0.001$ 
in digesta breakdown and passage leading to increased feed intake. The S. hamata supplement had probably increased the nitrogen available to the rumen microbes and this could have resulted in a more favourable rumen environment for increased microbial yield and subsequently the amount of protein absorbed from the duodenum (Van Soest, 1982; Preston and Leng, 1987).

Although the treatments appeared not to have affected the liveweights of the ewes, the slight improvement in the liveweights of all ewes could also be attributed to the combined effects of residual rice grains in the rice straw, which provided energy and more importantly, the ability of the $S$. hamata supplement to provide sufficient nitrogen and other nutrients for microbial fermentation.

The non-significance of the differences in the final liveweight and the final metabolic weights among the treatments could suggest that the $\mathrm{CP}$ contents of all the diets were at optimal level for the best performance in the animals as any $\mathrm{CP}$ level above the optimal could not induce any significant body weight increase.

\section{Treatment effects on pre-weaning lamb weights}

The higher average daily gains of the lambs whose dams were on $\mathrm{T}_{240}$ and $\mathrm{T}_{360}$ could be attributed to the higher total DM intake by ewes on these two treatments. As observed earlier the increased intake of $S$. hamata supplement increased the CP intakes accordingly and this probably had positive effects on milk composition and yield of ewes on these treatments $\left(\mathrm{T}_{240}\right.$ and $\left.\mathrm{T}_{360}\right)$. Consequently, lambs suckling ewes on these two treatments could translate the increased milk into superior liveweight gains. The average daily gains of the lambs were similar to values (35.18 - 48.39 g) obtained by Karbo and Alhassan, (1993) for lambs in Ghana. Rai et al. (1998) also reported an improvement in the weight of lambs after supplementing tropical grass hay with Stylosanthes.

\section{CONCLUSION}

The results of this study suggest that rice straw could be fed to lactating ewes as a dry season feed. However, there is the need to supplement with nitrogen sources such as Stylosanthes hamata at the rate of $240-360 \mathrm{~g} / \mathrm{d}$. Feeding of unused resources like rice straw with adequate supplementation in Ghana can increase the growth performance of lambs and maintain lactating ewes.

\section{ACKNOWLEDGEMENT}

The authors wish to acknowledge the support of the Director of the Animal Production Directorate of the Ministry of

\section{REFERENCES}

A.O.A.C. Association of Official Analytical Chemists. (1990). Official Methods of Analysis. $15^{\text {th }}$ Edition. Arlington, Virginia (USA).

Arigbede, O.M., Olanite, J.A. and Oni, A.O. (2004). Voluntary intake, digestibility and performance of WAD goats fed graded levels of Panicum maximum and Stylosanthes hamata. Proceedings of the Nigerian Society of Animal Production. 29: 355 - 359.

Buadu, M.K. and Osafo, E.L.K. (1994). The effect of mortality on the probable multiplication of sheep in the humid tropical zone in Ghana. Proceedings of the $22^{\text {nd }}$ Ghana Animal Science Association Symposium held at the University of Cape Coast, Cape Coast pp. 111-117.

Cesar, J., Zoumana, C., and Dulieu, D. (1999). The Panicum maximum/Stylosanthes hamata Forage Association in Cote D' Ivoire. Fourrages, 157: $5-20$.

Goering, H. K. and Van Soest, P. J. (1970). Forage Fibre Analysis (apparatus, reagents, procedures and some applications). Agricultural Handbook No 379. Washington DC (USA). Agricultural Research Service, United States Department of Agriculture. 
Humphreys, L. R. (1991). Pastures in animal cropping systems. In: Tropical Pasture Utilisation. Cambridge University Press, Cambridge. pp. $6-9 ; 133$.

Karbo, N. and Alhassan, W.S. (1993). The effect of supplementing rice straw to lactating ewes in the dry season in Northern Ghana. Proceedings of the Sixth Annual Conference of GSAP held at Cape Coast, 22-25 August, 1993. pp. 15-21.

Leng, R. A. (1990). Factors affecting the utilisation of 'poor quality' forages by ruminants particularly under tropical conditions. Nutrition Research Reviews 3: 277 - 303.

Mafwere, W. D. and Mtenga, L. A. (1992). Lablab (Dolichos lablab) meal as protein supplement for weaned fattening lambs. In: B. Rey, S.H.B. Lebbie and L. Reynolds (eds). Small Ruminant Research and Development in Africa. Proceedings of the First Biennial Conference of the African Small Ruminant Research Network, ILRAD, Nairobi, Kenya, 10 - 14 December 1990. ILCA (International Livestock Centre for Africa), Addis Ababa, Ethiopia, pp. 375 -386.

McManus, W. R., Manta, L., McFarlane, J. D. and Gray, A. C. (1972). Effects of diet supplementation and gamma irradiation on dissimilation of low quality roughages by ruminants. Journal of Agricultural Sciences, Cambridge 79: 55 - 66.

Moran, J. B., Satoto, K. B. and Dawson, J. E. (1983). The utilization of rice straw fed to Zebu cattle and swamp buffalo as influenced by alkali treatment and Leucaena supplementation. Australian Journal of Agricultural Research 34(1): 73 - 84.

Ngi, J., Ayaode, J.A. and Oluremi, O.I.A. (2006). Evaluation of dried cassava leaf meal and maize offal as supplements for goats fed rice straw in the dry season. Livestock Research for Rural Development. 18: 9.

Ngwa, A.T. and Tawah, C.L. (1991). Effect of legume crop residues and concentrate supple- mentation on voluntary intake and performance of Kirdi sheep fed a basal diet of rice straw. In: The complementarity of feed resources for animal production in Africa. Proceedings of the Joint Feed Resources Networks Workshop held in Gaborone, Botswana. 4 - 8 March, 1991. AFRNET, April, 1992. pp. 239-240.

Njwe, R. M. and Kona, B. (1998). Comparative evaluation of stylo (Stylosanthes guianensis) hay and concentrate as protein supplement for West African Dwarf sheep fed basal diet of elephant grass (Pennisetum purpureum). Small Ruminant Research Network Workshop. Pp. $231-234$.

Olson, K.C., Caton, J.S., Kirby, D.I.R and Norton, P.L. (1994). Influence of yeast culture supplementation and advancing season on steers grazing mixed grass praire in Northern great plains. Dietary composition, intake and in situ nutrient disappearance. Journal of Animal Science 8: 154-180.

Preston, T.R. and Leng, R.A. (1987). Matching ruminant production systems with available resources in the tropics and sub-tropics. Penambul Books Ltd. Armidale, New South Wales, Australia. pp 245.

Rai, P., Solanki, K.R., Roy, R.D. and Singh, R. (1998). Performance of lambs and kids on silvipastoral system and effects of grazing on constituent vegetation. Indian Journal of Animal Sciences 68: 973-975.

Rodriquez, A.A., Riquelme, E.O. and Randel, P.F. (1998). Inclusion of forage legumes in diets based on tropical grasses. Voluntary intake and nutrient digestibility. Journal of Agriculture of the University of Puerto Rico 82: 1-2; 39-49.

Siaw, D. E. K. A., Osuji, P. O. and Nsahlai, I. V. (1993). Evaluation of nutritive value of multipurpose tree germplasm: The use of gas production and rumen degradation characteristics. Journal of Agricultural Science (Cambridge) 120: 319 - 330. 
S.R.I.D. (Statistics, Research and Information Directorate) (2005). Agriculture in Ghana. Facts and Figures. Ministry of Food and Agriculture. Accra. Ghana.

Tuen, A. A., Dahan, M. M., Young, B. A. and Vijchulata, P. (1991). Intake and digestion of urea-treated, urea-supplemented and untreated rice straw by goats. Animal Feed Science and Technology 32: $333-340$.

Udo, T.M. and El-Harith, E.A. (1985). Feeding farm animals on unused resources in the tropics and sub-tropics. Animal Research and Development 22: 116 - 125.
Vadiveloo, J. (1992). Varietal differences in the chemical composition and in vitro digestibility of rice straw. Journal of Agricultural Science 119: $72-73$.

Van Soest, P. J. (1982). Nutritional Ecology of the Ruminant. O and B Books Inc., Corvallis, Oregon, USA. pp. 374.

Food and Agriculture (MoFA) for making available the facilities of the Sheep Breeding Farm at Ejura for this study. 